\title{
水洗による露出歯根の内毒素除去効果
}

光 㟝 潤子田 中 裕 子 大 竹 徹 長谷川 紘 司
昭和大学歯学部歯周治療学教室
(主任 : 長谷川紘司教授)
(昭和 63 年 9 月 16 日受付 $)$

\section{The Effect of Water Rinsing in Removal of Endotoxin from Exposed Root}

\author{
Junko MITSUZAKI, Hiroko TANAKA, Tohru OHTAKE and Kohji HASEGAWA \\ Department of Periodontics, Showa University Dental School \\ (Chief : Prof. Kohji HASEGAWA)
}

\begin{abstract}
Previous studies have revealed that periodontally involved exposed roots show evidence of biologic toxicity possibly due to endotoxin from subgingival micro-organisms.
\end{abstract}

Eleven periodontally involved teeth and five periodontally healthy teeth comprised the meterial. The teeth were rinsed in ultrasonic cleaner containing pyrogen-free water for one hour. The samples were taken from the solution after 1,5 , or 60 minutes. With the aim of removing residual endotoxin on the roots not eliminated by rinsing, each tooth was subjected to extraction of endotoxin with $45 \%$ phenol in water for 90 minutes at $65^{\circ} \mathrm{C}$. After extraction of endotoxin, the root surface of the involved teeth was further planed with a hand scaler. Endotoxin was extracted from the particles removed from the root surfaces. All samples were tested for endotoxin by limulus amoebocyte lysate assay.

The amount of endotoxin from involved teeth was $4,500 \pm 2,000 \mathrm{ng}$ per tooth and from healthy teeth it was $370 \pm 120 \mathrm{ng}$ per tooth. The amount of residual endotoxin on roots from involved teeth was $32 \pm 20 \mathrm{ng}$ per tooth and from healthy teeth it was $1.2 \pm 1.1 \mathrm{ng}$ per tooth. The amount of endotoxin collected from particles removed from previously rinsed involved root surfaces was $1.5 \mathrm{ng}$ per tooth. The rate of removal of endotoxin by water rinsing of a tooth was $64 \pm$ $25 \%$ in 1 minute, $85 \pm 16 \%$ in 5 minutes, $99 \pm 0.6 \%$ in 60 minutes.

From these findings, water rinsing of the exposed root was considered effective for removing endotoxin from the root surface.

Key words : Exposed root, Endotoxin, Water rinsing, Limulus lysate assay

要旨 : 水洗による露出歯根の内毒素の除去効果について検討する目的で, 歯周疾患罹患歯 11 歯, 非罹患 歯 5 歯を 抜去したままの状態で 1 時閒, 超音波洗浄を行なった。この洗浄液から，1分，5分，1時間の各時間の洗浄液中に溶 出した内毒素量を定量した。また，水洗後の歯根に残留している内毒素を，温フェノール水で抽出，定量した。さら に罹患歯ではフェノール処理後, 根面をルートプレーニングし, 削片から内毒素を抽出し, 定量した。その結果, 歯 根の内毒素量は, 罪患歯で 4,500 $2,000 \mathrm{ng}$, 非罹患歯で $370 \pm 120 \mathrm{ng}$ だった。罹患歯の水洗による歯根の内毒素の 除去率は, 1 分で, $64 \pm 25 \%, 5$ 分で $85 \pm 16 \%, 1$ 時間で $99 \pm 0.6 \%$ だった。以上のことより, 露出歯根の水洗は, 短時 間で，根面に付着あるいは浸透している内毒素の除去にきわめて効果的であることが示唆された。 
索引用語 : 露出歯根, 内毒素, 水洗, リムルス・テスト

\section{緒言}

歯周疾患に罹患し, 歯周ポケットが形成されると, 歯 周ポケット内には, 歯肉縁上プラークに比べ高い割合で グラム陰性菌を含む歯肉縁下プラークが形成される。

このような環境に曝された露出歯根は, 生物学的為害 性を示すことが知られている ${ }^{1 \sim 4)}$ 。この生物学的為害性 は, グラム陰性菌の細胞壁構造の一部である内毒素に多 くを依存すると考えられている ${ }^{5 \sim 8)}$ 。

Aleo $ら^{5)}$, Nishimine $ら^{6)}$, Jones $ら^{7)}$ は, 日常臨床で 広く普及しているスケーリング，ルートプレーニングを 行なうことで, 歯根に浸透あるいは付着している内毒素 を除去できると報告し, 露出歯根の機械的清掃の生物学 的意義を明らかにした。

大竹 ${ }^{9)}$ は, 露出歯根を水洗し, 培養系に移すと, 培養細 胞の歯根への付着が増加することから, 水洗により, 生 物学的為害物質, 特に内毒素が露出歯根から除去できる と報告し, 水洗による露出歯根の処置の可能性を示唆し た。

本実験は, 水洗による露出歯根の内毒素の除去効果に ついて，水洗時間とその除去率に関して検討する目的で 行なった。

\section{材料と方法}

昭和大学歯科病院保存科外来にて, 歯周疾患のため要 抜去と診断・抜去された単根歯 11 歯を歯周疾患罹 患 歯 として，また，矯正治療のため便宜抜去された第一小臼 歯 5 歯を歯周疾患非䍜患歯として実験に用いた。

被験歯は抜去後, プラーク・血液成分等を残存させた まま, 滅菌蒸留水 $30 \mathrm{~m} l$ の入った滅菌試験管内に静置 し, この試験管を $26 \mathrm{kHz}$ の超音波洗浄器 (Sinesonic 150 : 神明台工業株式会社製) 内に移し，水洗した。

超音波洗浄開始後, 1 分, 5 分, 1 時間の各時間におい て，それぞれの洗浄液中に溶出している内毒素量を測定 する目的で，各々の洗浄液から, $100 \mu l$ を試料として採 取した。

こうして，1時間水洗を行なった被験歯を洗浄液より 取り出し, 水洗後の歯根に残留している内毒素量を測定 する目的で, 各々の被験歯を, $65^{\circ} \mathrm{C}, 45 \%$ フェノール。
㐘周疾患非罹患歯断周疾患罹患㐘

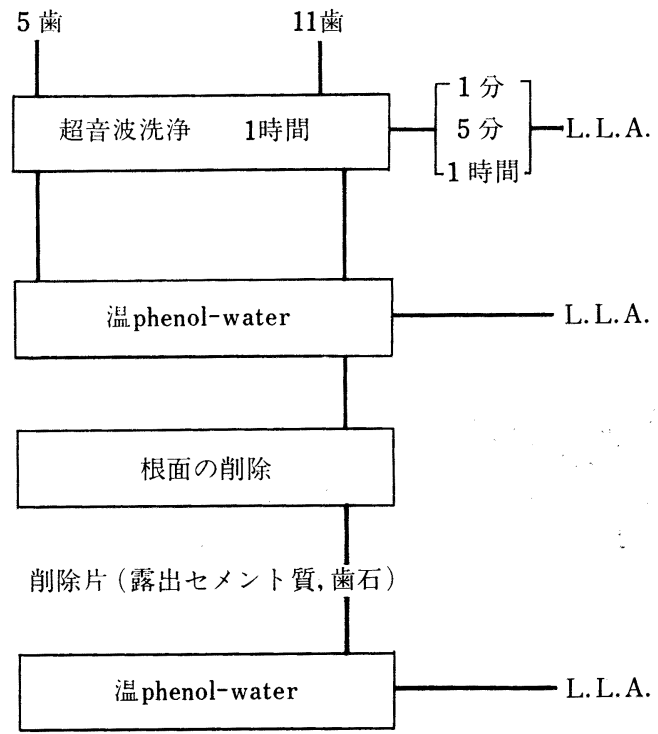

L. L. A.: Limulus Lysate Assay

図 1 実験方法

水 $10 \mathrm{~m} l$ で 90 分間処理し, 内毒素の抽出を行ない, 水層 より $100 \mu l$ を試料として採取した。また，歯周疾患罹 患歯では, 歯石や露出セメント質内に浸透し, 歯根表面 の水洗および温フェノール・水処理では抽出不可能な内 毒素が存在する可能性を検討するため, 11 歯の露出歯根 をハンドスケーラーを用いて，歯石および露出セメント 質を削除し, 歯周疾患罹患歯 11 歯の削除片を集めて, $65^{\circ} \mathrm{C}, 45 \%$ フェノール・水 $10 \mu l$ 中で 90 分間処理し, 水層から $100 \mu l$ を試料として採取した。こうして得ら れた試料は (1) 水洗 1 分後の洗浄液 (2) 水洗 5 分後の洗 浄液 (3) 水洗 1 時間後の洗浄液 (4) 水洗後の歯根をフェ ノール・水処理したもの (5) 水洗, フェノール・水処理 後の歯周疾患罹患歯 11 歯の歯根の削除片をさらにフェ ノール・水処理したものの計 5 種類の試料であった。

各試料を, 至適濃度に希釈後 $(1 / 100 \sim 1 / 20,000)$ 各試 料 $1 \mathrm{~m} l$ 中に含まれる内毒素量を, Limulus Lysate Assay キット (L.L.A.) [トキシ カラーシステム (生化学 工業社製)]にて定量した（図 1)。各処理によって得ら れた内毒素量は以下の計算式によって算定した。 [各試料 $1 \mathrm{~m} l$ 中に含まれる内毒素量 $] \times[$ 洗浄液の量ま たはフェノール水の水層の量] $\times$ 希釈倍数 
表 1 歯周疾患罹患歯の内毒素量 (ng)

\begin{tabular}{|c|c|c|c|}
\hline 歯 種 & $\begin{array}{l}1 \text { 時間の水洗で } \\
\text { 溶出した内毒素量 }\end{array}$ & 残留内毒素量 & 総内毒素量（※） \\
\hline$\overline{4}$ & 5,000 & 41 & 5,041 \\
\hline 3 & 4,300 & 44 & 4,344 \\
\hline 2 & 7,400 & 37 & 7,437 \\
\hline 1 & 1,800 & 13 & 1,813 \\
\hline$\overline{4}$ & 5,400 & 53 & 5,453 \\
\hline$\overline{1}$ & 3,600 & 48 & 3,648 \\
\hline$\overline{1}$ & 6,800 & 28 & 6,828 \\
\hline$\overline{2}$ & 7,000 & 4 & 7,004 \\
\hline 1 & 2,600 & 16 & 2,616 \\
\hline 2 & 1,900 & 8 & 1,908 \\
\hline$\overline{4}$ & 2,800 & 68 & 2,868 \\
\hline 平均値士標準偏差 & $4,400 \pm 2,000$ & $33 \pm 20$ & $4,500 \pm 2,000$ \\
\hline
\end{tabular}

※総内毒素量 $=1$ 時間の水洗で溶出した内毒素量 + 残留内毒素量

表 2 歯周疾患非罹患歯の内毒素 $(\mathrm{ng})$

\begin{tabular}{|c|c|c|c|}
\hline 歯 種 & $\begin{array}{l}1 \text { 時間の水洗で } \\
\text { 溶出した内毒素量 }\end{array}$ & 残留内毒素量 & 総内毒素量（※） \\
\hline 4 & 420 & 0.9 & 420.9 \\
\hline$\overline{4}$ & 560 & 0.5 & 560.5 \\
\hline$\overline{4}$ & 340 & 0.3 & 340.3 \\
\hline 4 & 340 & 3.4 & 343.4 \\
\hline$\underline{4}$ & 190 & 1.3 & 191.3 \\
\hline 平均値土標準偏差 & $370 \pm 120$ & $1.2 \pm 1.1$ & $371.2 \pm 120.3$ \\
\hline
\end{tabular}

※総内毒素量 $=1$ 時間の水洗で溶出した内毒素量 + 残留内毒素量

\section{結 果}

1. 1 時間の水洗により溶出した内毒素量（1 歯あた り)

（1）歯周疾患罹患歯（表 1 ）

$$
4,400 \pm 2,000 \mathrm{ng}
$$

（2）歯周疾患非罹患歯（表 2 ） $370 \pm 120 \mathrm{ng}$

2. 残留内毒素量 ( 1 歯あたり)

1 時間の水洗では除去できずに歯根面に残留していた 残留内毒素量は

（1）歯周疾患罹患歯（表 1） $33 \pm 20 \mathrm{ng}$

（2）歯周疾患非眻患歯（表 2 ） $1.2 \pm 1.1 \mathrm{ng}$
であった。

3. 総内毒素量 ( 1 歯あたり)

水洗 1 時間目に歯根から洗浄液へ溶出した 内 毒 素 量 と，水洗により除去できずに歯根に残留していた残留内 毒素量の和を総内毒素量とすると，

(1) 歯周疾患罹患歯 (表 1)

$$
4,500 \pm 2,000 \mathrm{ng}
$$

(2) 歯周疾患非罹患歯（表 2)

$$
370 \pm 120 \mathrm{ng}
$$

であった。

歯周疾患罹患歯と非罹患歯の総内毒素量を 比較する

と，罹患歯は非罹患歯の 10 倍以上の值を示した。

4. 露出歯根の削除片の内毒素量

歯周疾患罹患歯を 1 時間水洗し，さらにフェノール・ 水処理した後の露出セメント質と歯石の削除片から抽出 した内毒素量は, 11 歯の総量で $16 \mathrm{ng}, 1$ 歯あたり 1.5 


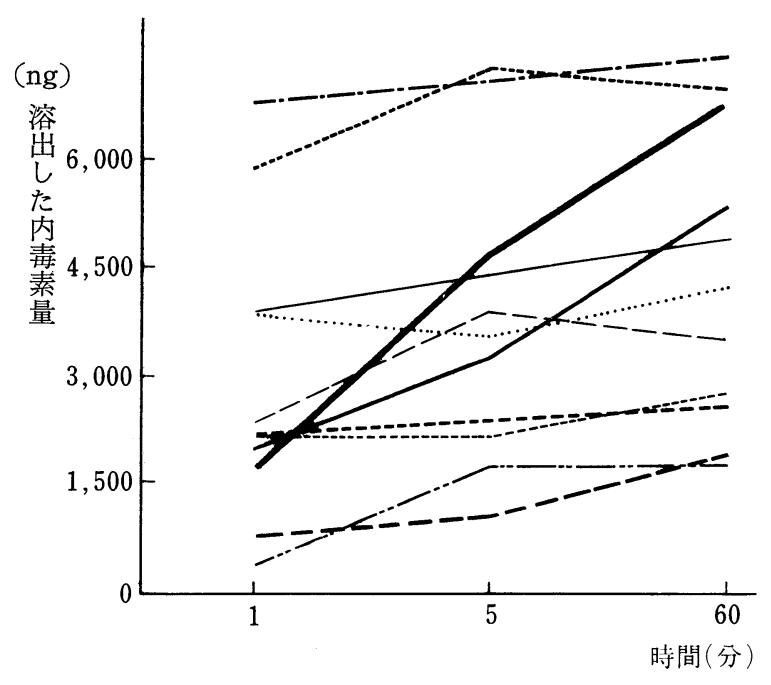

図 2 歯周疾患罹患歯の水洗により溶出した内毒素量 (ng)

表 3 歯周疾患罹患歯の水洗による内毒素の 除去率 (平均值士標準偏差)

\begin{tabular}{rc}
\hline 時間 (分) & 内毒素の除去率 $\quad(\%)$ \\
\hline 1 & $63.5 \pm 26.5$ \\
5 & $84.7 \pm 16.2$ \\
60 & $99.2 \pm 0.6$ \\
\hline
\end{tabular}

各時間における水洗で

内毒素の除去率 $=\frac{\text { 溶出した内毒素量 }}{\text { 総内毒素量 }} \times 100$ (\%)

ngであった。

5. 水洗による内毒素の除去効果

水洗による溶出した内毒素量を, 1 分, 5 分, 1 時間の 時間ごとにみると，歯周疾患罹患歯の歯根の内毒素のほ とんどが，短時間の水洗で溶出した（図 2 )。

また, 歯周疾患罹患歯の 1 分, 5 分, 1 時間の各時間に おける水洗で溶出した内毒素量の総内毒素に対する割合 を算出し，これを各時間における内毒素の除去率とし た。水洗による内毒素の除去効果を時間による除去率で みると,

1 分間で 約 $64 \pm 25 \%$

5 分間で 約 $85 \pm 16 \%$

1 時間で 約 $99 \pm 0.6 \%$ であった（表 3，図3）。

\section{考察}

本実験において，1 時間の水洗によって除去された】

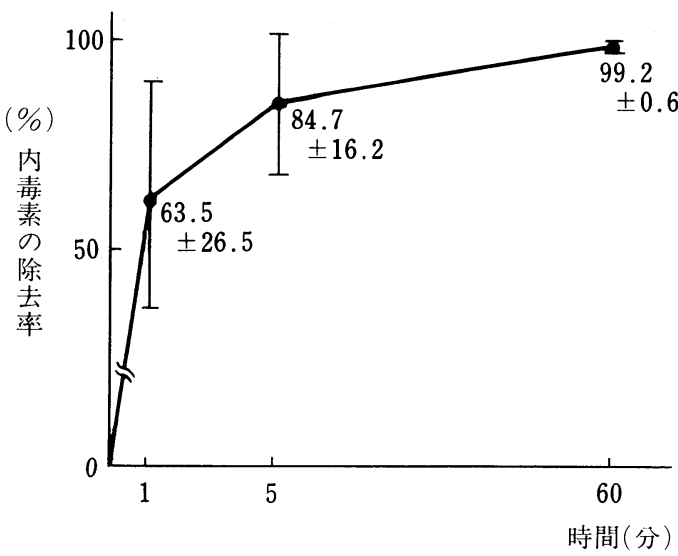

図 3 歯周疾患罹患歯の水洗による内毒素の除去率 (平均値士標準偏差)

毒素量と, 残留内毒素量の和を総内毒素量とすると, 歯 周疾患罹患歯では， 1 歯あたり $4,500 \pm 2,000 \mathrm{ng}$ と幅が あった。露出歯根の内毒素量を定量している報告はいく つかあるが，結果は様々である10,11)。

Cheetham $^{11)}$ は歯根面に付着している総内毒素量の差 は, 慢性炎症である歯周炎にみられる各部位ごとの病態 の差によるものが原因であると述べている。

これに対して, 歯周疾患非罹患歯の総内毒素量は 1 歯 あたり $370 \pm 120 \mathrm{ng}$ であり, これは, 他の研究者の報告 よりも大きな值であった。

Wilson ら ${ }^{10)}$ は, 埋伏智歯を抜去し, かるく水洗した 後に歯根を削除して削片の内毒素量を定量した。その内 毒素量は一歯あたり約 $3 \mathrm{ng}$ であったと報告している。

これに対し, 本実験では, 矯正治療のために便宜抜去 された第一小臼歯を用い, 抜去後根面は一切処置をせず, そのまま定量した。このように, 非罹患歯の総内毒素量 の他の研究者との差は, 被験歯の選択の違いや, 抜去の 際の污染などに起因していると考えられる。

Moore $ら^{12)}$ は, 歯周疾患罹患歯の露出歯根を, 1 分間 かるく水洗し,「ゆるく付着した物質」から抽出した内毒 素量は, 1 歯あたり平均 4,110 $4350 \mathrm{ng}$ (内毒素量全体 の $39 \%)$ ，さらに，1分間エンジンにつけた硬毛ブラシ でこすって除去できた物質から抽出した内毒素量は，1 歯あたり平均 $6,440 \pm 267 \mathrm{ng}$ (内毒素量全体の $60 \%$ ), こ れらの処置後にさらに歯根に残留していた内毒素量は,

1 歯あたり平均 $81 \pm 3.2 \mathrm{ng}$ (内毒素量全体の $1 \%$ ) であ ったと報告した。

本実験では 1 時間の水洗で 1 歯あたり $4,400 \pm 2,000$ ng の内毒素が抽出され，水洗後の歯根に残留していた 残留内毒素量は 1 歯あたり $33 \pm 20 \mathrm{ng}$ であった。水洗に 
より除去された内毒素量と残留内毒素量の和を総内毒素 量とすると, 総内毒素量に対する水洗による内毒素の除 去率は, 1 分間で $64 \pm 25 \%, 5$ 分間で $85 \pm 16 \%, 1$ 時間で $99 \pm 0.6 \%$ だった。

この 1 時間の水洗による内毒素の除去率は, Moore ら の行なった根面清掃によって除去された内毒素の割合と ほぼ一致している。

Nyman ら ${ }^{13}$ は，歯肉炎を惹起させたイ又を用い，歯 肉弁を剝離した後, スケーリングとダイヤモンド・バー による完全な露出セメント質の除去を行なった部位と, ラバーカップとペーストで研磨した部位の両者の治療を 組織学的に比較し, その治療状態はほとんど同じだった と報告した。

以上のことより, 歯石および露出セメント質を削除し なくても， 1 時間の水洗により, 露出歯根の内毒素のほ とんどが除去でき, さらに水洗後の歯根が周囲の歯周組 織に生物学的に受け入れられる状態になり得ることが示 唆された。

Nakib $^{14)}$ は, 歯周疾患罹患歯と健全歯を内毒素溶 液 に浸漬し，その切片を抗原抗体法にて調べた結果，セ メント質深部への浸透はみられなかったと報告した。

Hughes $ら^{15)}$ は, 歯周疾患罹患歯の露出セメント質の内 毒素の分布状態を免疫学的に調べたところ, 表層に限局 していたと報告した。

このように近年, 内毒素の露出セメント質への浸透性 に関する研究では, その深部への浸透性を疑問視してい る報告が多い16 18)。今回，水洗で $99 \%$ の内毒素が除去 でき,さらにフェノール処理後の歯石および露出セメン 卜質の削除片に残留していた内毒素は, 僅か $1.5 \mathrm{ng}$ で あった。この結果は，これらの報告を支持していると考 えられる。

露出歯根面の処理法には, 従来から行なわれてきたル ートプレーニングによる露出セメント質の全層削除が原 則として必要であるとされてきた6,7)。それに対し, 西村 らは，一度削除してしまったセメント質は二度と再生を しないため ${ }^{19)}$, 露出セメント質の削除は一層のみにとど めるべきであると主張している20)。大島 ${ }^{21)}$ は, 歯周疾患 罹患歯根面の線維芽細胞増殖抑制物質はセメント質の表 層 0〜20 $\mu \mathrm{m}$ の部分に局在していると報告している。こ のように近年, 露出歯根面の取り扱いについて, 従来の セメント質全層削除に異義が唱えられている。加えて, $\operatorname{Nyman}^{13)}$ によって, 露出セメント質の機械的削除を行 なわなくとも, 露出歯根を生物学的に周囲組織に受け入 れられる状態にすることが可能であるという報告がなさ
れている。

他方，歯周疾患の病因として大きな役割をはたす歯肉 縁下プラークを直接コントロールする方法として, direct irrigation が注目されてきているが，その評価は， ポケット内の非付着性プラーク除去の範囲にとどまって いる22)。

今回の実験結果から, 露出歯根の水洗処理は, 比較的 短時間で, 露出歯根に付着あるいは浸透している内毒素 の除去にきわめて効果的であり，このことから， direct irrigation における根面に対する水洗効果が期待でき る。

しかし，本実験の結果は，試験管内という閉鎖系の環 境下で得たものであり, 口腔内に開放されている歯周ポ ケット内に拉いてどの程度の有効性が得られるかという 点については, 今後の問題が残されている。

\section{結＼cjkstart論}

水洗による露出歯根の内毒素の除去効果について, 水 洗時間とその除去率について検討する目的で, Limulus Lysate Assayを用いて実験を行った。

1. 歯周疾患罹患歯 11 歯を 1 時間水洗して除去され た内毒素量は 1 歯あたり $4,400 \pm 2,000 \mathrm{ng}$ だった。

2. 1 時間の水洗後に歯周疾患罹患歯の露出歯根に残

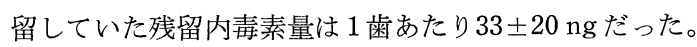

3. 歯周疾患䍜患歯 11 歯の総内毒素量は 1 歯あたり 4,500 $\pm 2,000 \mathrm{ng}$ だった。歯周疾患非罹患歯 5 歯の総内 毒素量は 1 歯あたり $370 \pm 120 \mathrm{ng}$ だった。

4. 歯周疾患罹患歯を 1 時間水洗し, フェノール処理 した後，歯根面をルートプレーニングして得た削片から 抽出された内毒素量は，1歯あたり $1.5 \mathrm{ng}$ だった。

5. 歯周疾患罹患歯の水洗による内毒素の除去率は, 1 分間で $64 \pm 25 \%, 5$ 分間で $85 \pm 16 \%, 1$ 時間で $99 \pm 0.6$ \%だった。

以上のことより，露出歯根の水洗は，比較的短時間で 歯根に付着あるいは浸透している内毒素の除去にきわめ て効果的であることが示された。

\section{文献}

1) Hatfield, C.G. and Baumhammers, A. : Cytotoxic effects of periodontally involved surfaces of human teeth. Archs oral Biol., 55 : 465-468, 1971. 
2) Morris, M.L. : The subcutaneous implantation of periodontally diseased roots. J. Periodontol., $43: 737-747,1972$.

3) Morris, M.L. : An inhibitory plinciple in the matrix of periodontally diseased roots. J. Periodontol., 46 : 33-39, 1975.

4) Aleo, J.J., DeRenzis, F.A., Farber, P.A. and Varboncoeur, A.P. : The presence and biologic activity of cementum-bound endotoxin. J. Periodontol., 45 : 672-675, 1974.

5) Aleo, J.J., DeRenzis, F.A. and Farber, P.A. : In vitro attachment of human gingival fibroblasts to root surfaces. J. Periodontol., $46: 639-645$, 1975.

6) Nishimine, D. and O'Lealy, T.J. : Hand instrumentation versus ultrasonics in the removal of endotoxins from root surfaces. J. Periodontol., $50: 345-349,1979$.

7) Jones, W.A. and O'Lealy, T.J. : The effectiveness of in vivo root planing in removing bacterial endotoxin from the roots of periodontally involved teeth. J. Periodontol., $49: 337-342$, 1978.

8) Daly, C.G., Seymour, G.J. and Kieser, J.B. : Bacterial endotoxin : a role in chronic inframmatory periodontal disease? J. Oral Pathol., $9: 1-15,1980$.

9）大竹 徹 : 露出セメント質の生物学的為害性に関 する研究. 日歯周誌, $28: 992-1003,1986$.

10) Wilson, M., Moore, J. and Kieser, J.B. : Identity of limulus amoebocyte lysate-active root surface materals from periodontally involved teeth. J. Clin. Periodontol., 13 : 743-747, 1986.

11) Cheetham, W.A., Wilson, M. and Kieser, J.B. : Root surface debridement-an in vitro assessement. J. Clin. Periodontol., 15 : 288-292, 1988.

12) Moore, J., Wilson, M. and Kieser, J.B. : The distribution of bacterial lipopolysaccharide (endotoxin) in relation to periodontally involved root surfaces. J. Clin. Periodontol., 13 : 748-751, 1986.

13) Nyman, S., Sarhed, G., Ericsson, I., Gottlow, J. and Karring, T. : Role of “diseased" root cementum in healing following treatment of periodontal disease. J. Periodontol. Res., 21 : 496-503, 1986.

14) Nakib, N.M., Bissada, N.F., Simmelink, J.W. and Goldstine, S.N. : Endotoxin penetration into root cementum of periodontally healthy and diseased human teeth. J. Periodontol., 53 : 368-378, 1982.

15) Hughes, F.J., Auger, D.W. and Smales, F.C. : Investigation of the distribution of cementumassociated lipopolysaccharides in periodontal disease by scanning electron microscope immunohistochemistry. J. Periodontol. Res., 23 : 100-106, 1988.

16) Eide, B., Lie, T. and Selvig, K.A. : Surface coatings on dental cementum incident to periodontal disease I. A scanning electron microscopic study. J. Clin. Periodontol., 10 : 157-171, 1983.

17) Eide, B., Lie, T. and Selvig, K.A. : Surface coatings on dental cementum incident to periodontal disease II. Scanning electron microscopic confirmation of amineralized cuticle. J. Clin. Periodontol., 11 : 565-575, 1984.

18）須田玲子，茂手木義男，宮下 元，長谷川紘司, 立川哲彦, 山本綾子 : セメント質への物質の浸透 性に関する実験 (II) (講演要旨). 日 歯 周 誌, 28 : 411-412, 1986.

19）西村和晃, 高田耕平, 野口吉広, 野口秀夫, 永石 真幸, 林 正純, 仲 秀典, 白井義英, 山岡 昭: 歯肉剝離搔爬手術後の新付着に関する研究（第 4 報)一術後の結合織付着部に対するX線定量分析 によるセメント質沈着の可能性について一，日歯 周誌, $27: 416-423,1985$.

20）西村和晃，高田耕平，野口吉広，永石真幸，林 正純, 白井義英, 山田 実, 山口十紀夫, 山岡 昭 : 歯肉剥離搔爬手術後の新付着に関する研究 (第 7 報)一污染セメント質に関する電子顕微鏡的 観察一. 日歯周誌, $27: 846-855,1985$.

21）大島光宏 : 細胞培養法を用いたスケーリング・ル ートプレーニングの効果に関する研究. 日歯周誌, $29: 65-75,1987$.

22) Greenstein, G. : Effects of subgingival irrigation on periodontal states. J. Periodontol., 58 : 827-836, 1987. 